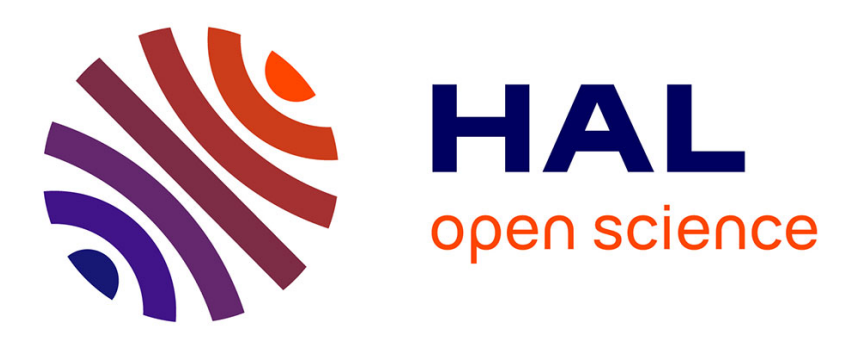

\title{
Equine embryo size does matter!
}

E. Derisoud, L. Jouneau, A. Margat, C. Gourtay, C. Dubois, C. Archilla, Y. Jaszczyszyn, M. Dahirel, N. Daniel, N. Peynot, et al.

\section{To cite this version:}

E. Derisoud, L. Jouneau, A. Margat, C. Gourtay, C. Dubois, et al.. Equine embryo size does matter!. 48th Annual Conference of the International Society of Embryo Technology, Jan 2022, Savannah, GA, United States. , Reproduction, Fertility and Development, 34 (1-2), pp.261, 2022, Proceedings of the Annual Conference of the International Embryo Technology Society, Savannah, Georgia, 10-13 January 2022. 10.1071/RDv34n2Ab52 . hal-03538184

\section{HAL Id: hal-03538184 https://hal.science/hal-03538184}

Submitted on 20 Jan 2022

HAL is a multi-disciplinary open access archive for the deposit and dissemination of scientific research documents, whether they are published or not. The documents may come from teaching and research institutions in France or abroad, or from public or private research centers.
L'archive ouverte pluridisciplinaire HAL, est destinée au dépôt et à la diffusion de documents scientifiques de niveau recherche, publiés ou non, émanant des établissements d'enseignement et de recherche français ou étrangers, des laboratoires publics ou privés. 


\section{INRAC Equine embryo size does matter!}

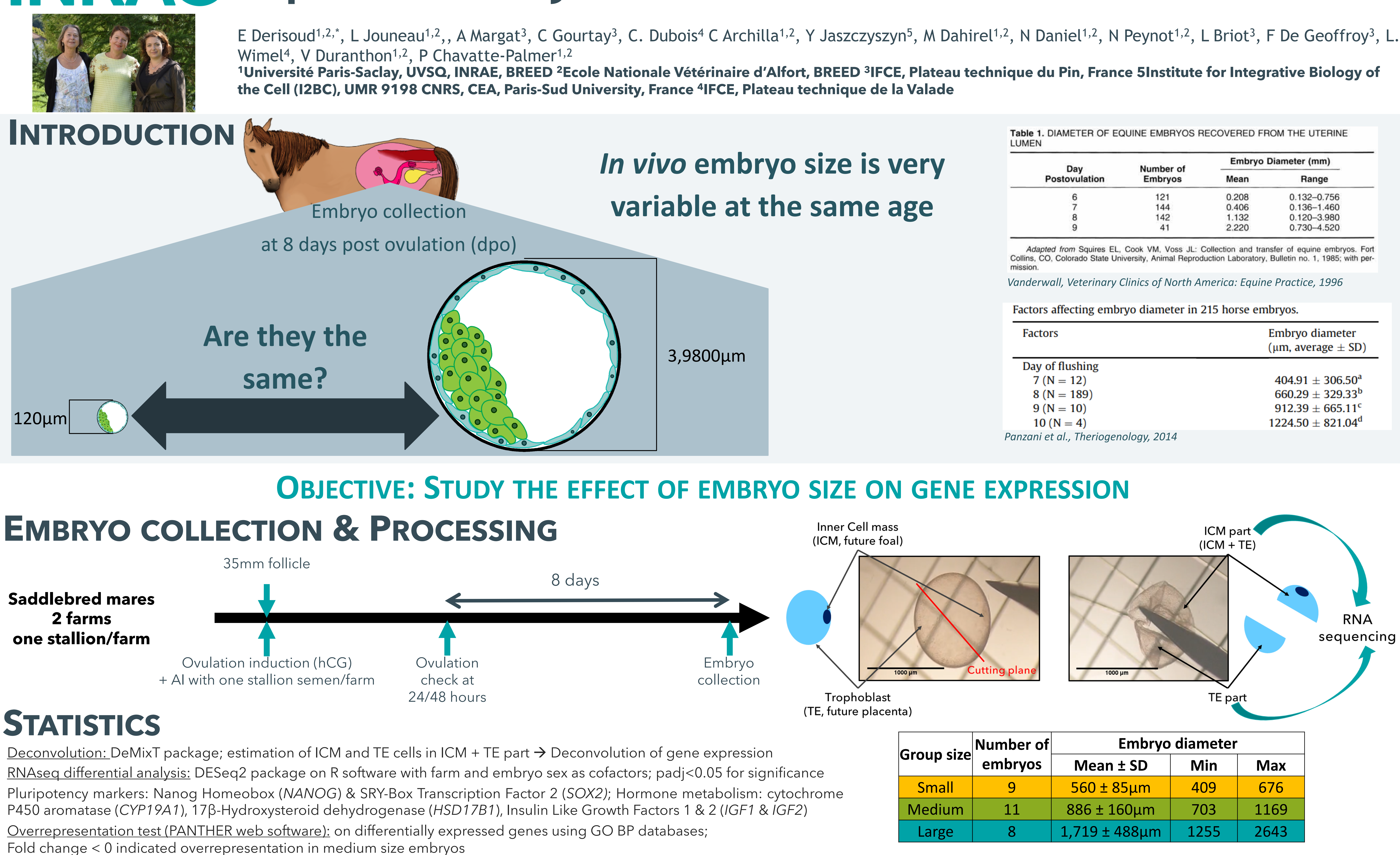

Fold change $<0$ indicated overrepresentation in medium size embryos

\section{RESULTS}

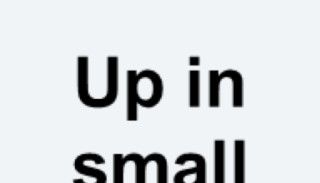

Up in

$479 \quad 13607 \quad 163$
Small vs Medium

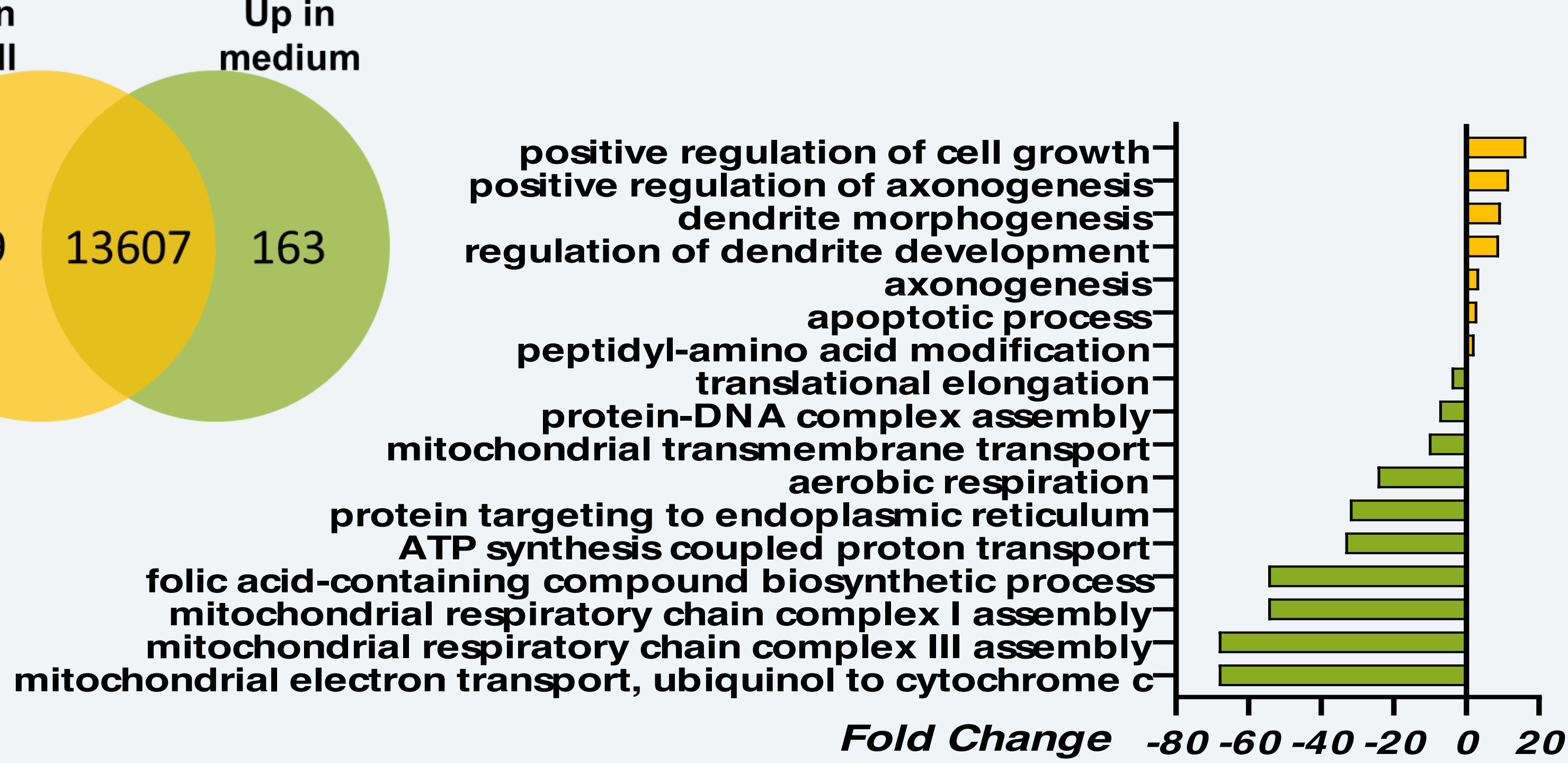

ICM

LARGE VS MEDIUM

Cell proliferation and differentiation seem to be more active in small embryos ICM $\rightarrow$ Maybe ICM of medium embryos has already enough cells and is less active in

cell proliferation at this stage

Mitochondria and aerobic respiration overrepresented in medium embryo ICM $\rightarrow$ small embryos do not seem to be able of $-------------1$

IGF2 is more expressed in ICM and TE of small embryos

s

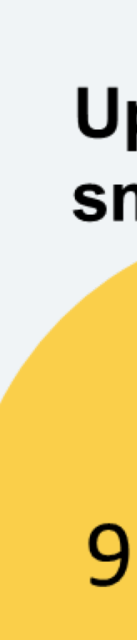

9

\section{CONCLUSIONS}

\begin{tabular}{|c|c|c|}
\hline NANOG & No difference & ২৬ in large embryos \\
\hline SOX2 & No difference & $\searrow \searrow$ in large embryos \\
\hline CYP19A1 & No difference & সイ in large embryos \\
\hline HSD17B1 & No difference & $\lambda$ in large embryos \\
\hline IGF1 & No difference & $\lambda$ in large embryos \\
\hline IGF2 & $r$ in small embryos & No difference \\
\hline CYP19A1 & No difference & No difference \\
\hline HSD17B1 & No difference & $\begin{array}{c}\text { Tended } \pi \text { in large } \\
\text { embryos }\end{array}$ \\
\hline IGF1 & No difference & $\checkmark$ in large embryos \\
\hline IGF2 & $\lambda$ in small embryos & No difference \\
\hline
\end{tabular}

\begin{tabular}{|l|} 
regulation of \\
negation \\
\hline embryos \\
\hline embryos \\
\hline embryos \\
\hline embryos \\
\hline in large \\
\hline embryos \\
\hline erence \\
\hline emce
\end{tabular}

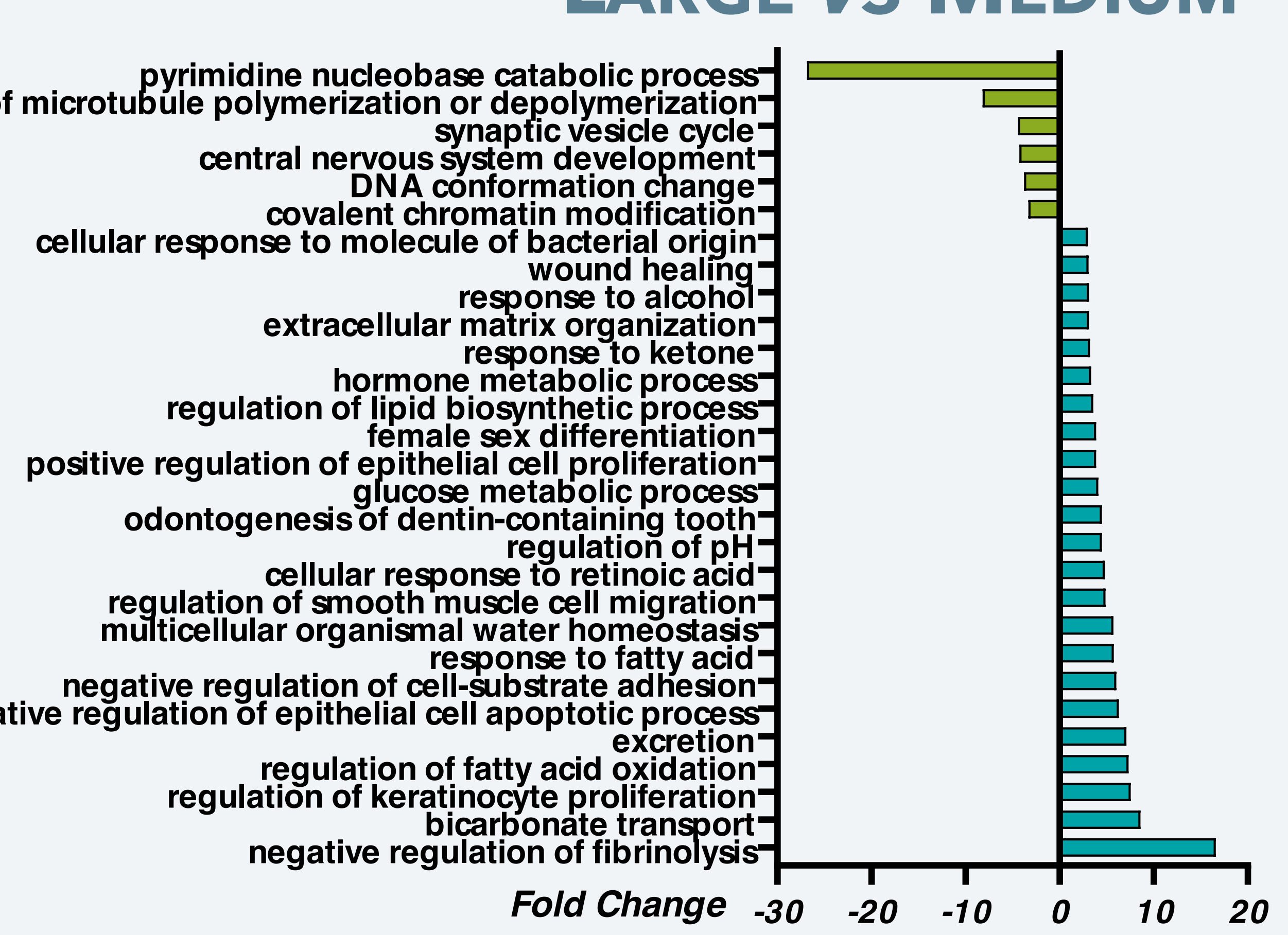

Reduced markers of pluripotency Modification of metabolic pathways and establishment $\rightarrow$ End of cell fate commitment?

Estrogen biosynthesis pathways: involved in maternal pregnancy IGF1 takes over IGF2 for embryo growth

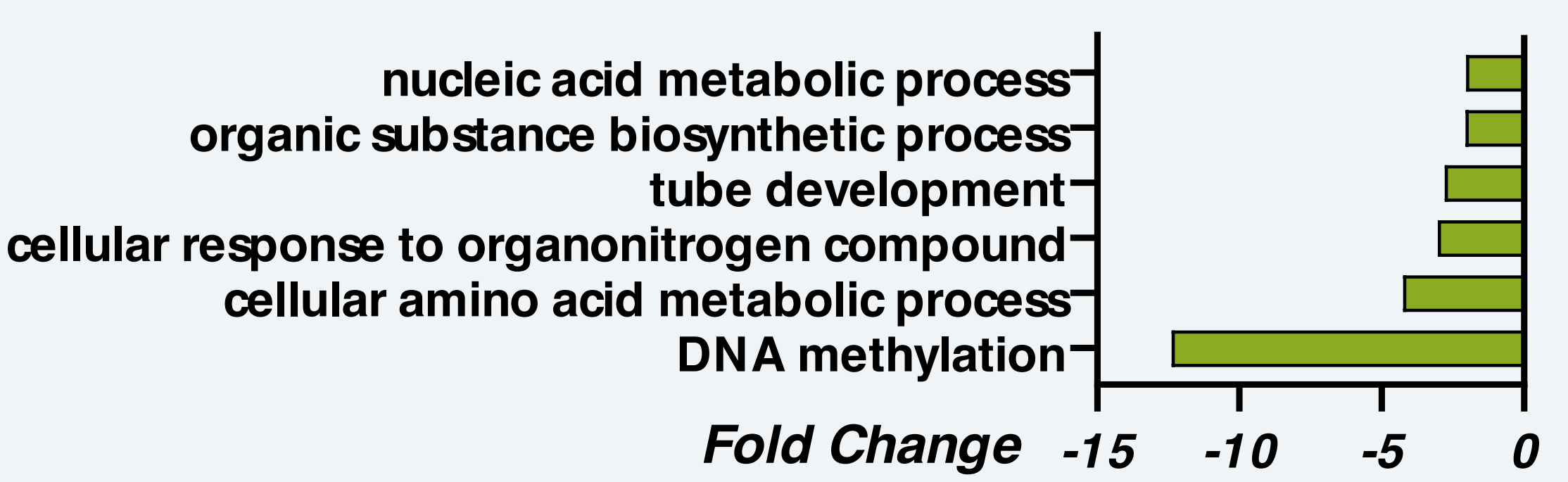

No overrepresented functions in large embryos but amino acid and nucleic acid metabolism overrepresented in medium embryos $\rightarrow$ Switch in energy sources?

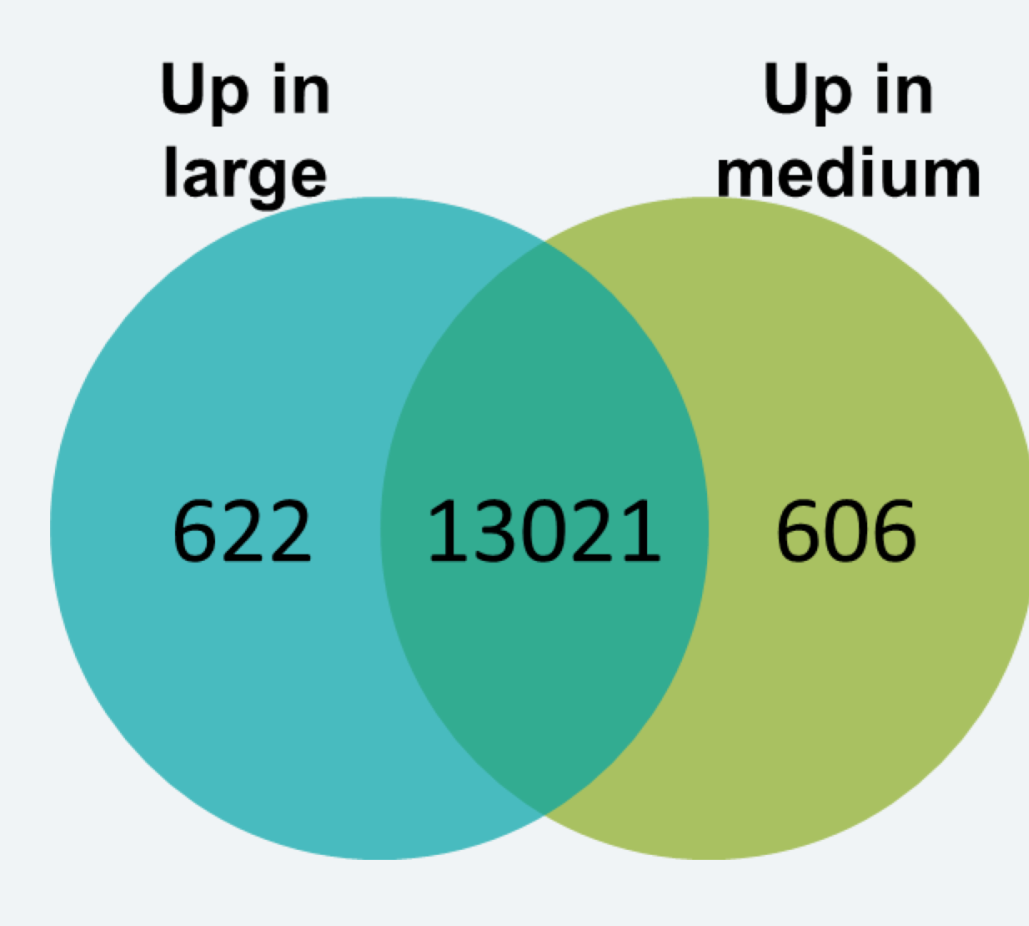
of regulatory processes

$\rightarrow$ glucose metabolism and aerobic respiration seem $\rightarrow$ glucose metabolism and aerobic respiration seem that require regulation pathways to avoid tan excess of oxidation in ICM cells

Developmental stage appears different

$\rightarrow$ Does a reduced speed growth or a later fertilization explain the differences?

$\rightarrow$ What are consequences for further development and implantation?

$\rightarrow$ Role of steroid biosynthesis pathways for maternal recognition of pregnancy?

Embryo size is important to consider when studying embryo gene expression

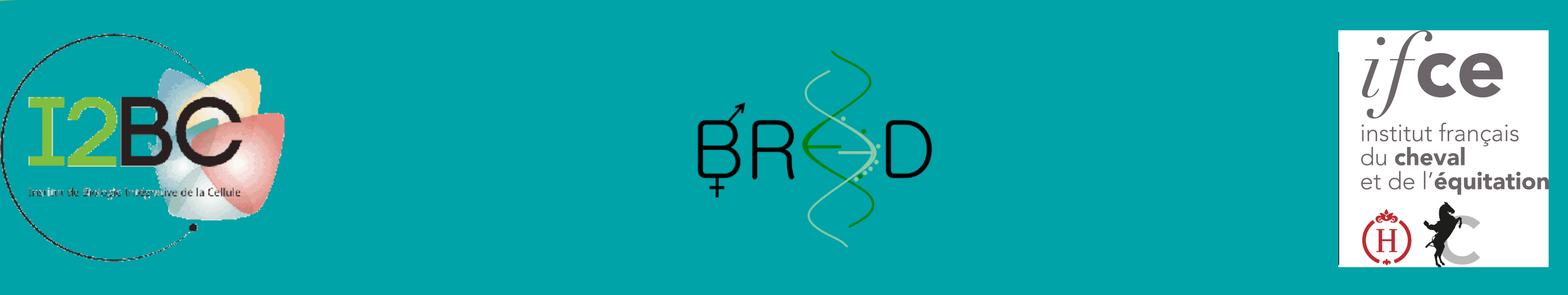

